\title{
Editorial
}

\section{Autoethnography: Writing Lives and Telling Stories}

\author{
Bal Chandra Luitel* and Niroj Dahal \\ Kathmandu University School of Education, Department of STEAM Education, Hattiban, \\ Lalitpur, Nepal \\ Email: bcluitel@kusoed.edu.np and niroj@kusoed.edu.np \\ 0000-0002-5483-2385, (iD) 0000-0001-7646-1186
}

\begin{abstract}
Autoethnography covers a wide range of narrative representations, thereby bridging the gap of the boundaries by expressing autoethnographers' painful and gainful lived experiences. These representations arise from local stories, vignettes, dialogues, and role plays by unfolding action, reaction, and interaction in the form of self-narration. Likewise, the autoethnographic texts must exhibit the autoethnographers' critical reflections on the overall process of the inquiry. These exhibitions shall alert the autoethnographers' research ethics, reflexivity, alternative modes of representation, inquiry, and storytelling. The original articles in this issue that rises from the domain of critical social theories within the various ranges of theoretical perspectives include journeying through informing, reforming, and transforming teacher education; critical ethnographic research tradition; a critical and political reading of the excerpts of myths; climate change education and its interface with indigenous knowledge and general traits of the participants as transformed teachers.
\end{abstract}

Keywords: Autoethnography. Narrative. Vignette. Critical. Storytelling.

\section{Introduction}

Autoethnography covers broad areas of narrative representations of various contexts of engagements, such as developing educational programs, implementing culturally responsive pedagogies, and addressing humanitarian crises (Luitel \& Dahal, 2020). These representations offer the autoethnographers ways of bridging the gap of boundaries between humanities and social sciences. In this process, the autoethnographers express their painful and gainful lived experiences via multiple forms of expressions, such as poetic, visual, performative, multi-voiced, dialogue, and co-constructed stories, thereby making use of local stories, vignettes, conversations, and role play by unfolding action, reaction, and interaction in the form of self-narration. Likewise, autoethnographers might generate conscience via critical reflections on the overall process of the inquiry.

\begin{tabular}{|c|c|c|}
\hline $\begin{array}{l}\text { *Corresponding Editor. } \\
\text { (c) (i) (2) (2) }\end{array}$ & (c) The Editors, 2021. & $\begin{array}{l}\text { ISSN: 2717-5081 (Print); 2738-9529 (Online) } \\
\text { Journal Webpages: } \\
\text { 1. http://www.kusoed.edu.np/journal/index.php/jtp } \\
\text { 2. https://www.nepjol.info/index.php/jrtp/ }\end{array}$ \\
\hline
\end{tabular}


Writing lives and telling stories as inquiry is likely to raise the consciousness of the researchers, participants, and readers. The raising of consciousness of the researchers and participants can be reflected in their present and future actions and reflections. Likewise, the act of writing lives and telling stories is not limited to showcasing narrative representations and gaining insights, but also performing in the world. These performances shall cover the process and outcomes to the great diversity of contexts of the research. The goal of writing lives and telling stories is "cultivating the critical conscience of researchers, practitioners, participants, and actors through ethical and participatory engagement in the lifeworld" (Luitel \& Dahal, 2020, p. 1). More so, "examining beliefs, assumptions, and activities via writing lives and telling stories offers the practitioners some forms of the transformative sensibilities to improve actions, thereby creating better systems" (Dale \& Hyslop-Margison, 2010, p. 74).

This editorial discusses autoethnography as a critical project. Our notion of the critical project is all about challenging ongoing unjust practices by cultivating critical sensibilities. Likewise, the multiple ways of knowing in autoethnography are multi-model forms while recalling experiences that are embedded in researchers' actions and their meanings ranging from analytical to evocative. The multiparadigmatic design space offers the opportunity for the researchers to embrace multiple ways of interpreting and meaning-making their lived stories. Axiological orientation in autoethnography is about upholding values that influence the entire research process. Transformative professional development emphasises the change grounded within the socio-cultural frame of reference for developing researchers' identities by highlighting empowerment and social justice. The analytical and evocative autoethnography are basic tenets of the autoethnography as analytical autoethnography promotes a normative agenda and evocative autoethnography blends the narrative of our emotional lifeworld.

\section{Autoethnography as Critical Project}

Our notion of autoethnography as a critical project is associated with raising the agenda of social justice and empowerment through storytelling practices and life writing. The personalis-political is the central idea of a critical project. This idea is about rewriting critical theory in context by challenging the status quo, injustices, and inequalities. Likewise, critically informed stories encourage the readers and researchers to depict performatives to view the world from their perspectives as change agents. Inherently, autoethnography as a critical project is about cultivating critical sensibilities in any issues under study. Critical theory shall provide a space for emancipation to the autoethnographers, so that the idea is not a static object but an ongoing process of reconstruction and emergence (Holman Jones, 2016). This process of reconstruction links thinking and actions as "living bodies of thought" (Pollock, 1998, p. 74). Such linkages could be reflected through storytelling and life-writing as experienced from personal to social spheres.

\section{Multiple ways of Knowing}

One might say writing in autoethnography is easier in terms of recalling personal and professional experiences. Nevertheless, autoethnographies "are highly personalized accounts that draw upon the experience of the autoethnographers to extend sociological understanding" (Sparkes, 2000, p. 21). An autoethnography "lets you use yourself to get to culture" (Pelias, 2003, p. 372) in multi-model forms, such as felt, expressed, observed, reasoned, etc. Recalling experiences is contingent upon the researcher's current beliefs and values, thereby unraveling multiplicities embedded in our actions and their meanings. Thus, writing these experiences is driven by multiple epistemologies ranging from analytical to 
evocative. Therefore, autoethnography promotes multiple ways of knowing by giving multiple voices to personal experiences, thereby cultivating deep, soulful, in/tangible, subjective and objective knowledge systems.

\section{Multiparadigmatic Design Space}

Multiparadigmatic design space offers autoethnographers multiple ways of interpreting and meaning making of their lived stories. Autoethnography embraces multi-paradigmatic design space as researchers need to ground their narratives in context, reflect critically on taken-forgranted assumptions, and use arts-based approaches in representing experiences (Luitel \& Taylor, 2019). These multiparadigmatic design spaces blend the different paradigms, such as interpretivism (i.e., meaning), criticalism (i.e., critique), postmodernism (i.e., arts-based methods), etc.

The changing nature of human behaviors is the area of interpretivism. Human behaviors cannot be probed by the methods of natural science (Cohen et al., 2011). The interpretive research paradigm in autoethnographic inquiry promotes researchers' interactivity with their lived experiences (Pant, 2015; Shrestha, 2018; Pant, 2019). More so, the interpretive paradigm helps generate a context-based understanding of the phenomenon as it is from subjective experiences of individuals' thoughts, beliefs, values associated with social actions (Taylor et al., 2012). As an interpretive researcher, thick descriptions (cf. quick descriptions) are necessary to understand the phenomenon under study. Autoethnographers should engage deeply to understand the cultural phenomenon while creating life through stories.

Criticalism helps the autoethnographer to examine practices by reflecting critically on 'self' and 'others' to identify and transform socially unjust structures, beliefs, and practices (Kincheloe \& Mclaren, 2000). Autoethnographers, as critical researchers, are considered change agents who incorporate advocacy and the performative dimension of knowing (Taylor et al., 2012). Likewise, the critical paradigm enables autoethnographers to resist unjust traditions, beliefs, and practices. Thus, the paradigm of criticalism helps autoethnographers enable themselves and others by exercising critical reflexivity as a process standard of the research.

The postmodern paradigm is viewed as a window for autoethnographers to look into self and other minds through subjective lenses so that researchers' narratives can capture inaccessible and ineffable realities (e.g., beliefs, attitudes, values, emotions), and present them using various forms of logic and genres (Luitel, 2012; Qutoshi, 2015). Dialectical, poetic, narrative, and metaphorical are some of them. Likewise, the postmodern research paradigm adds pluralism and liveliness to the research works by providing a rich repertoire of the modes of inquiry (Taylor, 2014). The new forms of representation can be helpful for autoethnographers to explore their lived and living experiences in different ways of expression, such as poems, stories and plays.

The integral paradigm is viewed as a synthesizer for covering the broad spectrum of epistemologies. This holistic view from different perspectives arising from the paradigms of interpretivism, criticalism, and postmodernism enables autoethnographers to reflect on and capture a broader meaning of practices by offering possible alternatives to the issue under investigation (Taylor et al., 2012). Likewise, reflection enables autoethnographers to think holistically about options to construct the vision of life-affirming educational practices. In the process of capturing alternative meanings, autoethnographers use multiple logics and genres, imagination, perspectival language in narrating their lived experiences (Taylor, 2013). These writing processes shall enable autoethnographers to use multiple epistemic metaphors that garland multiple views and provide an opportunity to connect self, others, and beyond. In this 
way, the integral view offers autoethnographers to employ the metaphor of the One-andMany in which multiplicities are united within a collective whole.

\section{Axiological Orientation}

An autoethnography as a process and product requires any antirealist ontological, nonpositivist epistemological, and value-laden axiological positions of researchers (Ellis et al., 2010). Likewise, in autoethnography, axiological orientation gives rise to ontological and epistemological positions from problematizing to writing up research. Axiological orientation in autoethnographic inquiry is value laden. Axiological orientation is about choosing values positionality that influences the entire research process of storying lived experiences of the researchers and research participants. Likewise, autoethnographers need to value the normative and opposing perspectives throughout the research process-before, during, and after the generation of filed texts. This process combines the multiple realities that may emerge during the research process.

\section{Transformative Professional Development}

In general, transformative professional development is guided by transformative learning theory. This learning theory provides a framework for continuous growth through critical reflection (Cranton et al., 2003). The broader concepts of transformative professional development highlight the change of the habit of mind for inclusion and empowerment. In this line, action plans, reflective activities, and critical discourses are some of the strategies for transformative professional development. Mezirow (1981) describes "the emancipatory process of becoming critically aware of how and why the structure of psycho-cultural assumptions has come to constrain the way we see ourselves and our relationships, reconstituting this structure to permit a more inclusive and discriminating integration of experience and acting upon these new understandings" (pp. 6-7). Likewise, the professional development process is unique and changeable (Mezirow, 1991). Autoethnography is a learning process of constructing and appropriating new, revised, and reflective interpretations of existing meaning and action systems.

Autoethnography is likely to open the door for new epistemological spaces for educators to examine their cultural situatedness through critical reflexivity (Taylor, 2013). Therefore, the central question of the inquiry is: how can the researchers engage in reflecting critically about themselves and systems? Thus, transformative professional development involves a process of critically examining their own (and others') personal and professional values and beliefs, which help develop inclusive visions of their actions (Mezirow, 2000; Taylor et al., 2012). Critical self-reflection involves questioning deep-seated assumptions, thereby emphasizing newer understandings and learnings for activities that enable self and others (Mezirow, 1991).

Transformative professional development is grounded within the socio-cultural approach of developing researchers' identities by highlighting personal empowerment and social transformation (Freire, 1972). Professionals are viewed as agents of social change. They must be aware of the social and political dimensions of practices. Eventually, this process enables professionals as researchers awakening to engage in an authentic dialectical process thereby gradually moving towards a non-contradictory meaning space called conscientization (Freire, 1972). 


\section{Analytic and Evocative Autoethnography}

In autoethnography, analytical and evocative schools of thought are prominent. Anderson (2006) defines "The term analytic autoethnography to refer to research in which the researcher is (1) a full member in the research group or setting, (2) visible as such a member in published texts, and (3) committed to developing theoretical understandings of broader social phenomena" (p. 1). Analytic autoethnographers must practice narrative visibility of the self and others, exercise analytic reflexivity, dialogue with self and others, and promote an analytical agenda. Opposing Anderson (2006), Ellis and Bochner (2006) emphasize by responding to the question-how do researchers connect intellectually and emotionally to readers' lives throughout the process of representing their lived experiences? Evocative autoethnography is the composition of narrative without bracketing our emotional lives, thereby including painful and gainful lived experiences of autoethnographers. Ellis and Bochner (2006) intend to see the autoethnographers in the 'autoethnography' so autoethnographers shall transform their private troubles into public, making it robust, comforting, vulnerable, and culturally essential. These two schools of thought in autoethnography help explore objective and subjective dimensions of the same phenomenon. Analytic autoethnography aims to bridge the ethnographic and narrative traditions; evocative autoethnography is considered equally important in connecting the emotional self with the socio-political agenda. For us, the analytical and the evocative co-dependently arise; one cannot be conceived without the other.

\section{Some Caveats}

While responding to the question - how autoethnographers represent their identities, power relations, privileges, pain, pleasure, and vulnerabilities -- autoethnography encourages researchers to represent their personal and professional lived experiences. Thus, autoethnography gives rise to the authorial power to represent self and others in many possible ways. There is a possibility that autoethnographers receive the blame of being and adhering to narcissism, solipsism, and aestheticism (Ploder \& Stadlbauer, 2016). Narcissism is a common limitation in autoethnographic inquiry. It might promote self-admiration by the researcher as a lone hero. Solipsism is about being too self-centric, not establishing a clear theoretical standpoint, and lacking convincing arguments and scholarly rigor in making claims and representing them. Aestheticism emphasizes the artistic values of autoethnographies rather than the research agenda.

\section{Volume 2 Issue 1 Covers}

This issue of the Journal includes five original articles. Sadruddin Bahadur Qutoshi reflected his journey on curriculum images as a teacher educator in Pakistan. While addressing 'how does an auto/ethnographic muse explore informing, reforming, and transforming states of teacher education and research practices?', he critiques informing and reforming states of teacher education in Pakistan. Indra Mani Rai and Prabin Rai exhibited their critical ethnographic research tradition by exploring how Mangsuk as an indigenous institution represents a space for cultural-self and relational knowing in the Yamphu indigenous community of a village in Nepal. Saroj G.C offers a critical and political reading of the excerpts of myths included in the English language textbooks of Nepal and looks at how the content is more prone to instilling particular values than critical language skills. Pasang Dolma Sherpa addresses climate change education and its interface with indigenous knowledge systems. She explores the potential for transformation towards more holistic 
climate change education that balances science and indigenous knowledge. Hem Raj Kafle unfolds four aspects of ethos in six English teachers - spontaneity, specialties, specialization, and stability - and six frames of reference corresponding with the transformative journey of each participant - teaching is living, made for teaching, making things happen, empowering female students, performing the ideal image and position in the opposition.

\section{List of References}

Anderson, L. (2006). Analytic autoethnography. Journal of Contemporary Ethnography, 35(4), 373-395. https://doi.org/10.1177/0891241605280449

Cohen, L., Manion, L., \& Morrison, K. (2011). Research methods in education. Routledge.

Cranton, P., \& King, K. P. (2003). Transformative learning as a professional development goal. New Directions for Adult and Continuing Education, 98, 31-37.

Dale, J., \& Hyslop-Margison, E. J. (2010). Paulo Freire: Teaching for freedom and transformation: The philosophical influences on the work of Paulo Freire (Vol. 12). Springer Science \& Business Media.

Ellis, C. S., \& Bochner, A. P. (2006). Analyzing analytic autoethnography: An autopsy. Journal of contemporary ethnography, 35(4), 429-449. https://doi.org/10.1177/0891241606286979

Ellis, C., Adams, T. E., \& Bochner, A. P. (2010). Autoethnography: An overview. Forum Qualitative Sozialforschung / Forum: Qualitative Social Research, 12(1). https://doi.org/10.17169/fqs-12.1.1589

Freire, P. (1972). Pedagogy of the oppressed. Penguin.

Habermas, J. (1972). Knowledge and human interest. Heinemann.

Holman Jones, S. (2016). Living bodies of thought: The "critical" in critical autoethnography. Qualitative Inquiry, 22(4), 228-237. https://doi.org/10.1177/1077800415622509

Kincheloe, J. L., \& McLaren, P. (2000). Rethinking critical theory and qualitative research. In N. K. Denzin \& Y. S. Lincoln (Eds.), Handbook of qualitative research ( $2^{\text {nd }}$ ed.) (pp. 279-313). Sage Publication.

Luitel, B. C. (2009). Culture, worldview and transformative philosophy of mathematics education in Nepal: A cultural-philosophical inquiry [Unpublished doctoral thesis]. Science and Mathematics Education Centre, Curtin University, Perth, Australia

Luitel, B. C., \& Dahal, N. (2020). Conceptualising transformative praxis. Journal of Transformative Praxis, 1(1), 1-8. https://doi.org/10.3126/jrtp.v1i1.31756

Luitel, B. C., \& Taylor, P. C. (2019). Introduction: Research as transformative learning for sustainable futures. In Research as Transformative Learning for Sustainable Futures (pp. 1-16). Brill Sense.

Luitel, B. C., \& Wagley, S. (2017). Transformative educational research: Fleshing out the concepts. Journal of Education and Research, 7(1), 1-10.

Mezirow, J. (1981). A critical theory of adult learning and education. Adult Education Quarterly, 32(1), 3-24.

Mezirow, J. (1991). Transformative dimensions of adult learning. Jossey-Bass.

Mezirow, J. (2000). Learning as transformation: Critical perspectives on a theory in progress. Jossey Bass.

Montagud Mayor, X. (2016). Analytic or Evocative: A forgotten discussion in autoethnography. Forum: Qualitative Social Research, 17(3). https://doi.org/10.17169/fqs-17.3.2432

Pant, B. P. (2015). Pondering on my beliefs and practices on mathematics, pedagogy, curriculum and assessment [Unpublished MPhil Dissertation]. Kathmandu University, Nepal. 
Pant, B. P. (2019). An integral perspective on research: Methodological and theoretical journey of a teacher educator. In Research as Transformative Learning for Sustainable Futures (pp. 75-87). Brill Sense.

Pelias, R. J. (2003). The academic tourist: An autoethnography. Qualitative Inquiry, 9(3), 369-373.

Ploder, A., \& Stadlbauer, J. (2016). Strong Reflexivity and its Critics: Responses to Autoethnography in the German-speaking cultural and social sciences. Qualitative Inquiry, 22(9), 753-765.

Pollock, D. (1998). Performing writing. The Ends of Performance, 73-103.

Qutoshi, S. (2015). Auto/ethnography: A transformative research paradigm. Dhaulagiri Journal of Sociology and Anthropology, 9, 161-190. https://doi.org/10.3126/dsaj.v9i0.14027

Shrestha, I. M. (2018). My pedagogical sensitisation towards holistic mathematics education: A practitioner's inquiry [Unpublished MPhil Dissertation]. Kathmandu University, School of Education.

Sparkes, A. C. (2000). Autoethnography and narratives of self: Reflections on criteria in action. Sociology of Sport Journal, 17, 21-43.

Taylor, E. W. (2017). Transformative learning theory. In Transformative learning meets bildung (pp. 17-29). Brill Sense.

Taylor, P. C. (2013). Research as transformative learning for meaning-centred professional development. Meaning-centred education: International Perspectives and Explorations in Higher Education, 168-185.

Taylor, P. C. (2014). Contemporary qualitative research: Toward an integral research perspective. In N.G. Lederman \& S.K. Abell (Eds.), Handbook of research on science education (Vol. II, pp. 38-54). Routledge.

Taylor, P.C., Taylor, E., \& Luitel, B.C. (2012). Multi-paradigmatic transformative research as/for teacher education: An integral perspective. In K. G. Tobin, B. J. Fraser \& C. McRobbie (Eds.), Second international handbook of science education (pp. 373- 387). Springer.

Willis, J. W. (2007). Foundations of qualitative research. Sage.

\section{Suggested Citation:}

Luitel, B. C., \& Dahal, N. (2021). Autoethnography: Writing lives and telling stories [Editorial]. Journal of Transformative Praxis, 2(1), 1-7. https://doi.org/10.51474/jrtp.v2i1.530 